\title{
Ocular Adnexal Lymphoma cM1a TNM
} Finding v8

National Cancer Institute

\section{Source}

National Cancer Institute. Ocular Adnexal Lymphoma CM1a TNM Finding v8. NCI

Thesaurus. Code C140855.

Ocular adnexal lymphoma with noncontiguous involvement of tissues or organs external to the ocular adnexa (e.g., parotid glands, submandibular gland, lung, liver, spleen, kidney, breast). (from AJCC 8th Ed.) 